\title{
Pengaruh Kecerdasan Emosional terhadap Prestasi Belajar Siswa Kelas IV SD Selama Pembelajaran Daring
}

\author{
Wasiul Maghfiroh*, Putri Mahanani, Nihayati \\ Universitas Negeri Malang, Jl. Semarang No. 5 Malang, Jawa Timur, Indonesia \\ *Penulis korespondensi, Surel: wasiulmaghfiroh.412@gmail.com
}

Paper received: 5-7-2021; revised: 23-7-2021; accepted: 30-7-2021

\begin{abstract}
This research was conducted with the aim of knowing whether there is a positive and significant effect of emotional intelligence on the learning achievement of fourth grade elementary school students in cluster 4 of Blimbing sub-district during online learning. This research uses a quantitative approach, with an associative type. Based on the results of simple linear regression analysis, the equation $\mathrm{Y}$ is $51.912+0.364 \mathrm{X}$ is obtained, it can be seen that the consistent value of variable $\mathrm{Y}$ is 51.912 , while the regression coefficient for variable $X$ is 1.339. The regression coefficient $X$ is positive, so it can be said that the effect of variable $X$ on variable $Y$ has a positive direction of influence. Based on the probability value obtained, which is 0.000 less than 0.05 , it shows that variable $\mathrm{X}$ has an effect on variable $Y$. At the $t$ value, it is known that $t_{\text {count }} 4.815$ greater than $t_{\text {table }} 1.657$, which means that the regression coefficient is significant. That way, it can be concluded that there is a positive and significant effect of emotional intelligence on the learning achievement of fourth grade elementary school students in cluster 4 of Blimbing sub-district during online learning.
\end{abstract}

Keywords: emotional intelligence; learning achievement; online learning

\begin{abstract}
Abstrak
Penelitian ini dilakukan dengan tujuan untuk mengetahui ada tidaknya pengaruh positif dan signifikan kecerdasan emosional terhadap prestasi belajar siswa kelas IV SD se-gugus 4 kecamatan Blimbing selama pembelajaran daring. Penelitian ini menggunakan pendekatan kuantitatif, dengan jenis asosiatif. Berdasarkan hasil analisis regresi linear sederhana, diperoleh persamaan Y sama dengan 51,912 + 0,364X, dapat diketahui nilai konsisten variabel Y sebesar 51,912, sedangkan koefisien regresi variabel $X$ sebesar 1,339. Koefisien regresi $X$ bernilai positif, sehingga dapat dikatakan bahwa pengaruh dari variabel $\mathrm{X}$ terhadap variabel $\mathrm{Y}$ memiliki arah pengaruh yang positif. Berdasarkan nilai probabilitas yang didapatkan yakni 0,000 kurang dari 0,05 , menunjukkan bahwa variabel X berpengaruh terhadap variabel Y. Pada nilai t, diketahui thitung 4,815 lebih dari tabel 1,657, yang berarti koefisien regresi dinyatakan signifikan. Dengan begitu, dapat diperoleh kesimpulan bahwa ada pengaruh positif dan signifikan kecerdasan emosional terhadap prestasi belajar siswa kelas IV SD se-gugus 4 kecamatan Blimbing selama pembelajaran daring.
\end{abstract}

Kata kunci: kecerdasan emosional; prestasi belajar; pembelajaran daring

\section{Pendahuluan}

Pendidikan tidak akan lepas dari kegiatan pembelajaran. Secara umum pendidikan dapat diperoleh melalui pembelajaran di sekolah. Namun pada saat ini tatanan pendidikan telah berubah, sehingga berdampak pada pelaksanaan kegiatan pembelajaran pada umumnya. Sistem pembelajaran yang mulanya bertemu secara fisik antara guru dengan siswa, diganti dengan pemanfaatan jaringan dalam pelaksanaannya (Mahanani, dkk., 2020). Hal ini mengacu pada Surat Edaran Nomor 4 Tahun 2020 yang dikeluarkan oleh Menteri Pendidikan dan Kebudayaan Republik Indonesia tentang Pelaksanaan Kebijakan Pendidikan dalam Masa Darurat Penyebaran Corona Virus Disease (Covid-19). Pembelajaran jarak jauh seperti ini dikenal dengan istilah pembelajaran daring. Sebagaimana dijelaskan oleh Sadikin \& Hamidah 
(2020) dimana pembelajaran daring dalam pelaksanaan berbagai jenis interaksi pembelajarannya memanfaatkan jaringan internet, aksesibilitas, konektivitas, dan fleksibilitas. Sehubungan dengan itu, siswa dialihkan untuk melakukan kegiatan belajar secara mandiri di rumah masing-masing dalam upaya penekanan angka penyebaran virus Covid-19.

Seperti halnya pembelajaran di sekolah, pembelajaran daring pun memiliki tantangan tersendiri dalam pelaksanaannya. Adapun tantangan dalam pembelajaran daring yakni keberadaan siswa dan guru yang terpisah saat melakukan pembelajaran, hal tersebut berakibat pada gaya mengajar guru yang pastinya mengalami perubahan. Selama melakukan pembelajaran daring, guru dituntut untuk dapat lebih kreatif dengan harapan pembelajaran dapat berjalan lancar dan tujuan pembelajaran yang direncanakan dapat dicapai oleh siswa (Mahanani, dkk., 2020). Disamping itu, guru juga akan mengalami kesulitan untuk mengawasi siswa secara langsung. Guru tidak dapat memastikan apakah siswa sungguh-sungguh dalam belajar (Sadikin \& Hamidah, 2020).

Kesungguhan siswa dalam belajar akan dapat mempengaruhi keberhasilan dalam belajarnya. Kesungguhan dalam belajar sepenuhnya tergantung pada diri siswa itu sendiri, bagaimana siswa dapat mengelola dirinya dengan baik. Hal ini erat kaitannya dengan kecerdasan emosional dari setiap siswa. Sebagaimana dijelaskan Daud (2012) bahwa kecerdasan emosional bertumpu pada keterkaitan antara perasaan, watak, serta naluri yang berkenaan dengan pengendalian diri, dapat semangat dan tekun, penyesuaian diri, kemampuan dalam pemecahan masalah, dapat mengendalikan diri dari amarah, dan kemampuan dalam memotivasi diri sendiri, utamanya dalam proses pembelajaran.

Selama pembelajaran daring seperti ini, kecerdasan intelektual saja tidak akan cukup untuk mengantar siswa menuju kesuksesan dalam belajar. Karena kecerdasan emosional juga dapat mendukung kesuksesan siswa dalam belajar, sehingga faktor kecerdasan emosional memiliki peran penting dalam pembelajaran. Seorang siswa dengan kecerdasan emosional tinggi, dapat ditandai dari perilaku yang ditunjukkan, seperti mampu mengenali dan mengelola emosi yang muncul dari dalam dirinya, mampu memotivasi dirinya untuk belajar, mampu berempati kepada orang lain, dan dapat membangun hubungan yang baik bersama orang lain. Hal tersebut didukung oleh Leoh, dkk (2019) bahwa apabila siswa belum mempunyai kecerdasan emosional yang baik, dalam belajarnya ia cenderung mudah putus asa dan menyerah, serta ia akan merasa takut untuk bertanya kepada teman maupun guru apabila ia menjumpai masalah yang berkaitan dengan belajarnya.

Berdasarkan hasil wawancara bersama guru kelas IV sekolah dasar yang ada di gugus 4 kecamatan Blimbing yang terdiri dari lima sekolah, diperoleh hasil bahwa terdapat beberapa permasalahan selama pembelajaran daring seperti siswa yang enggan menyelesaikan tugas dari guru terutama jika tugas tulis, siswa yang enggan mengerjakan tugas sedikitpun, siswa yang tidak mengumpulkan tugas meskipun fasilitas di rumahnya dapat dikatakan cukup memadai karena siswa yang bersangkutan merupakan anak dari seorang PNS, siswa yang suka menunda-nunda dalam mengerjakan tugas sekolah sehingga telat mengumpulkan tugas bahkan hingga empat hari atau lebih, ada pula siswa yang tidak pernah hadir ketika diadakan pembelajaran melalui google meet, selain itu terdapat siswa yang kurang mampu mengontrol dirinya untuk bisa bertanggung jawab terhadap dirinya sendiri dalam kegiatan belajar sehingga siswa menyalahgunakan penggunaan handphone dalam pembelajaran, dan ada pula siswa yang semangat belajarnya menurun sehingga guru menduga bahwa yang mengerjakan 
adalah orang tuanya jika dilihat dari bentuk tulisannya. Nilai siswa yang bermasalah seperti ini akan berbeda dengan siswa yang rajin dan mengumpulkan tugas dengan disiplin, karena guru mengungkapkan bahwa nilai untuk siswa yang bermasalah seperti ini akan diberikan di batas KKM (Kriteria Ketuntasan Minimal).

Guna menyelidiki penyebab munculnya masalah-masalah seperti demikian, perlu dilakukan penelitian tentang pengaruh kecerdasan emosional terhadap prestasi belajar siswa. Hal ini didukung oleh Basir (2019) dimana hasilnya menunjukkan adanya hubungan signifikan antara kecerdasan emosional dengan prestasi belajar siswa pada pelajaran PAI di SMPIT Iqra' kota Bengkulu.

Berdasarkan uraian di atas, peneliti bermaksud melakukan penelitian tentang "Pengaruh Kecerdasan Emosional terhadap Prestasi Belajar Kelas IV SD se-Gugus 4 Kecamatan Blimbing selama Pembelajaran Daring". Alasan dipilihnya gugus 4 kecamatan Blimbing yakni karena permasalahan yang muncul paling besar terkait kecerdasan emosional ditemukan di gugus 4 kecamatan Blimbing, dan dilakukannya penelitian ini di kelas IV karena siswa kelas IV dirasa lebih mampu menerima dengan baik jika dikenalkan tentang kecerdasan emosional, dengan maksud siswa dapat sedini mungkin menyiapkan dirinya melewati peralihan masa dari kanak-kanak menuju masa remaja agar memiliki kesiapan yang terbilang cukup maksimal dalam mengenali dirinya sendiri untuk menjadi pribadi yang sukses di masa depannya.

\section{Metode}

Penelitian ini menggunakan pendekatan kuantitatif asosiatif. Hal ini didasarkan pada tujuan penelitian yakni ingin mengetahui ada tidaknya pengaruh dari variabel bebas (variabel kecerdasan emosional) terhadap variabel terikat (variabel terikat). Sebagaimana dijelaskan oleh Timotius (2017) bahwa penelitian asosiatif dimaksudkan untuk menyelidiki adanya hubungan atau pengaruh antara dua variabel atau lebih.

Data dikumpulkan melalui tiga teknik, yakni wawancara, angket, dan dokumentasi. Wawancara dilakukan dengan mewawancarai guru kelas IV pada masing-masing sekolah dasar di gugus 4 kecamatan Blimbing, untuk mendapatkan data awal pendukung pelaksanaan penelitian ini. Angket digunakan untuk mengukur variabel kecerdasan emosional siswa. Dokumentasi digunakan untuk memperoleh data prestasi belajar siswa kelas IV yang berupa data penilaian harian siswa pada pembelajaran tematik tema 7. Data yang dikumpulkan melalui angket sebelumnya diuji validitas terlebih dahulu oleh validator ahli, dan diuji coba kepada 10 siswa di luar sampel penelitian untuk menguji reliabilitasnya.

Setelah data terkumpul, selanjutnya data diuji prasyarat terlebih dahulu. Pertama, yakni uji normalitas. Uji normalitas dilakukan guna mengetahui normal atau tidaknya hasil angket kecerdasan emosional dan hasil prestasi belajar siswa. Pengujian normalitas dilakukan dengan berbantuan SPSS Statistic 22 menggunakan uji Kolmogorov-Smirnov. Data dianggap berdistribusi normal apabila nilai p > tingkat signifikansi 0,05 dengan jumlah sampel $>50$ (Hulu \& Sinaga, 2019). Kedua, yakni uji linearitas. Apabila ingin mengetahui dua variabel memiliki hubungan yang linear atau tidak, maka perlu dilakukan uji linearitas. Syarat untuk bisa menguji linearitas yaitu data yang dimiliki minimal terdiri dari satu variabel bebas dan variabel terikat (Marzuki, dkk., 2020). Pengujian linearitas pada penelitian ini dilakukan dengan bantuan SPSS Statistic 22. Adapun cara dalam pengambilan keputusan pada uji linearitas menurut Marzuki, dkk (2020) yakni dengan melihat nilai signifikansi yang diperoleh. Ketika diperoleh nilai signifikan $>0,05$, dapat dikatakan bahwa variabel bebas dan variabel terikat mempunyai 
hubungan yang linear secara signifikan. Sebaiknya, ketika nilai signifikan $\leq 0,05$ maka tidak terdapat hubungan yang linear secara signifikan antara variabel bebas dengan variabel terikat.

Setelah dilakukan uji prasyarat, selanjutnya dilakukan analisis regresi linear sederhana. Pengujian analisis regresi linear sederhana dalam penelitian ini dibantu dengan SPSS Statistic 22. Adapun ketentuan yang digunakan yakni, setelah didapatkan nilai $r$, selanjutnya ialah menarik kesimpulan jika $r_{\text {htung }}>r_{\text {bbel }}$ dengan taraf signifikansi 0,05 , berarti terdapat hubungan signifikan dan begitupun sebaliknya. Pengambilan kesimpulan adanya hubungan atau tidak, dapat pula dilihat berdasarkan nilai probabilitas yang dihasilkan. Apabila nilai $p<0,05$, berarti dapat dinyatakan terdapat hubungan yang signifikan antara variabel independen dengan variabel dependen, begitu pula sebaliknya (Hulu \& Sinaga, 2020).

Beberapa langkah dalam analisis regresi linear sederhana yaitu (a) Menghitung $\Sigma \mathrm{X}, \Sigma \mathrm{Y}$, $\sum \mathrm{X}^{2}, \sum \mathrm{Y}^{2}$, dan $\sum \mathrm{XY}$, (b) Mencari nilai a dan b, (c) Mencari persamaan regresi linear sederhana, (d) Menguji koefisien korelasi variabel X dan variabel Y. Adapun rumus-rumus yang digunakan berturut-turut seperti di bawah ini.

$$
\begin{aligned}
a & =\frac{(\Sigma Y)\left(\Sigma X^{2}\right)-(\Sigma Y)(\Sigma X Y)}{\mathrm{n} \sum \mathrm{X}^{2}-\left(\sum \mathrm{X}\right)^{2}} \\
\mathrm{~b} & =\frac{\mathrm{n} \sum \mathrm{XY}-\left(\sum \mathrm{X}\right)\left(\sum \mathrm{Y}\right)}{\mathrm{n} \sum \mathrm{X}^{2}-\left(\sum \mathrm{X}\right)^{2}} \\
\breve{Y} & =\mathrm{a}+\mathrm{bX} \\
r & =\frac{\mathrm{n} \cdot \sum \mathrm{XY}-\sum \mathrm{X} \cdot \sum \mathrm{Y}}{\sqrt{\left[\mathrm{n} \cdot \Sigma \mathrm{X}^{2}-\left(\sum \mathrm{X}\right)^{2}\right]\left[\mathrm{n} \cdot \Sigma \mathrm{Y}^{2}-\left(\sum \mathrm{Y}\right)^{2}\right]}} \\
t & =\frac{r \sqrt{n-2}}{\sqrt{1-r^{2}}}
\end{aligned}
$$

Mengacu pada (1), $\sum X$ merupakan jumlah keseluruhan dari pengamatan pada variabel $\mathrm{X}$ yakni skor angket kecerdasan emosional, $\sum Y$ merupakan jumlah keseluruhan dari pengamatan pada variabel Y yakni penilaian harian siswa pada pembelajaran tematik tema 7 , $\sum X_{2}$ merupakan jumlah kuadrat dari pengamatan pada variabel $X$ yakni skor angket kecerdasan emosional, $\Sigma X Y$ merupakan jumlah perkalian seluruh pengamatan pada variabel $\mathrm{X}$ dan $\mathrm{Y}$ yaitu skor angket kecerdasan emosional dan penilaian harian siswa pada pembelajaran tematik tema 7, dan $n$ merupakan banyaknya pengamatan dari sampel yang ditetapkan, yakni 131 siswa kelas IV SD se-gugus 4 kecamatan Blimbing. Mengacu pada (2), $a$ merupakan konstanta (nilai $Y$ jika $X=0$ ), $b$ merupakan koefisien regresi, jika ada kenaikan memiliki tanda + (plus) atau penurunan yang memiliki tanda - (minus) terhadap nilai $Y$ apabila $X$ berubah 1 unit, $Y$ merupakan variabel terikat, dan $X$ merupakan variabel bebas. Mengacu pada (3), $r$ merupakan rumus koefisien korelasi, $n$ merupakan banyaknya sampel yang ditetapkan.

\section{Hasil dan Pembahasan}

Data pada penelitian ini didapatkan dari 131 siswa kelas IV SD pada gugus 4 kecamatan Blimbing yang meliputi data hasil angket kecerdasan emosional sebagai variabel $\mathrm{X}$ dan data prestasi belajar dari penilaian harian siswa selama pembelajaran daring, tepatnya pada pembelajaran tematik tema 7 sebagai variabel Y. Adapun data tersebut dapat dilihat pada Tabel 1. 
Jurnal Pembelajaran, Bimbingan, dan Pengelolaan Pendidikan, 1(7), 2021, 552-562

Tabel 1. Data Hasil Angket Kecerdasan Emosional (X) dan Prestasi Belajar Siswa (Y)

\begin{tabular}{|c|c|c|c|c|c|c|c|c|c|c|c|}
\hline No & Responden & $\mathbf{X}$ & $\mathbf{Y}$ & No & Responden & $\mathbf{X}$ & $\mathbf{Y}$ & No & Responden & $\mathrm{X}$ & $\mathbf{Y}$ \\
\hline 1 & AADW & 100 & 91 & 46 & GSP & 102 & 80 & 91 & $\mathrm{NF}$ & 100 & 86 \\
\hline 2 & AAP & 108 & 98 & 47 & HDB & 94 & 100 & 92 & NK & 90 & 86 \\
\hline 3 & AASWA & 84 & 80 & 48 & HDR & 84 & 89 & 93 & NKP & 92 & 94 \\
\hline 4 & ABP & 80 & 80 & 49 & HPS & 95 & 80 & 94 & NLW & 72 & 87 \\
\hline 5 & ABS & 81 & 86 & 50 & IDPS & 77 & 74 & 95 & NNP & 94 & 88 \\
\hline 6 & ADBR & 83 & 80 & 51 & IHP & 89 & 79 & 96 & NNU & 101 & 90 \\
\hline 7 & $\mathrm{AF}$ & 90 & 90 & 52 & IMZ & 101 & 95 & 97 & NO & 93 & 87 \\
\hline 8 & AFR & 85 & 89 & 53 & INPY & 80 & 77 & 98 & NZY & 69 & 86 \\
\hline 9 & AFRI & 77 & 70 & 54 & INR & 105 & 89 & 99 & ODA & 91 & 80 \\
\hline 10 & AIA & 96 & 89 & 55 & IQD & 78 & 63 & 100 & PKJ & 82 & 84 \\
\hline 11 & AL & 88 & 85 & 56 & ITA & 83 & 80 & 101 & PSPY & 95 & 94 \\
\hline 12 & ALPA & 104 & 92 & 57 & JAW & 75 & 91 & 102 & PTAY & 75 & 75 \\
\hline 13 & AOP & 116 & 90 & 58 & JDPR & 98 & 92 & 103 & QNH & 93 & 70 \\
\hline 14 & APS & 93 & 89 & 59 & JRR & 97 & 92 & 104 & RA & 97 & 71 \\
\hline 15 & APW & 91 & 86 & 60 & KAC & 78 & 100 & 105 & RAA & 89 & 84 \\
\hline 16 & ARF & 82 & 85 & 61 & KDP & 110 & 95 & 106 & RAP & 98 & 92 \\
\hline 17 & ARF & 85 & 86 & 62 & KLN & 104 & 90 & 107 & RAPS & 72 & 68 \\
\hline 18 & ASNA & 100 & 95 & 63 & KNS & 101 & 92 & 108 & RBA & 99 & 90 \\
\hline 19 & ASRP & 91 & 94 & 64 & KYA & 85 & 75 & 109 & RDM & 110 & 95 \\
\hline 20 & AVR & 79 & 88 & 65 & LA & 89 & 82 & 110 & RFM & 81 & 91 \\
\hline 21 & AWSR & 83 & 80 & 66 & LPR & 106 & 92 & 111 & RNS & 89 & 88 \\
\hline 22 & AZIN & 91 & 84 & 67 & MAAG & 86 & 95 & 112 & RPAR & 72 & 72 \\
\hline 23 & BAP & 99 & 87 & 68 & MAAS & 97 & 88 & 113 & RSW & 95 & 89 \\
\hline 24 & BR & 83 & 81 & 69 & MAW & 102 & 80 & 114 & RYP & 93 & 88 \\
\hline 25 & BRAS & 94 & 89 & 70 & MAY & 81 & 84 & 115 & SAN & 111 & 72 \\
\hline 26 & BWS & 97 & 84 & 71 & MBA & 88 & 88 & 116 & SAP & 80 & 72 \\
\hline 27 & CCR & 102 & 98 & 72 & MCI & 74 & 80 & 117 & SF & 89 & 100 \\
\hline 28 & CDMP & 89 & 86 & 73 & MFA & 78 & 74 & 118 & SFA & 88 & 70 \\
\hline 29 & CJM & 96 & 86 & 74 & MFDS & 103 & 100 & 119 & SFAT & 90 & 62 \\
\hline 30 & DAH & 105 & 88 & 75 & MH & 89 & 86 & 120 & SOCF & 99 & 98 \\
\hline 31 & DAP & 104 & 93 & 76 & MMFR & 100 & 81 & 121 & SYA & 96 & 72 \\
\hline 32 & DKRL & 103 & 98 & 77 & MMS & 90 & 84 & 122 & TEN & 75 & 73 \\
\hline 33 & DPW & 100 & 94 & 78 & MNAG & 93 & 80 & 123 & TSR & 94 & 100 \\
\hline 34 & DSA & 101 & 88 & 79 & MNF & 93 & 79 & 124 & VD & 97 & 80 \\
\hline 35 & ERB & 71 & 70 & 80 & MNIP & 90 & 89 & 125 & VNA & 88 & 64 \\
\hline 36 & EYAP & 78 & 96 & 81 & MNKA & 101 & 79 & 126 & YPBP & 81 & 94 \\
\hline 37 & FAB & 78 & 91 & 82 & MRA & 96 & 96 & 127 & ZALP & 92 & 85 \\
\hline 38 & FAMP & 98 & 88 & 83 & MRAZP & 89 & 75 & 128 & ZMA & 98 & 80 \\
\hline 39 & FDS & 85 & 85 & 84 & MRB & 88 & 79 & 129 & ZSF & 92 & 80 \\
\hline 40 & FFRU & 98 & 92 & 85 & MRP & 102 & 64 & 130 & ZSW & 93 & 84 \\
\hline 41 & FHPS & 96 & 98 & 86 & MRR & 87 & 82 & 131 & ZTPS & 78 & 61 \\
\hline 42 & FPA & 81 & 79 & 87 & MYCP & 94 & 83 & & & & \\
\hline 43 & FRS & 98 & 94 & 88 & NA & 91 & 100 & & & & \\
\hline 44 & GAR & 90 & 76 & 89 & NANN & 102 & 94 & & & & \\
\hline 45 & GRR & 88 & 90 & 90 & NAZ & 83 & 72 & & & & \\
\hline
\end{tabular}

\subsection{Pembuktian Instrumen Angket}

\subsubsection{Uji Validitas}

Pengujian validitas dalam penelitian ini dilakukan oleh dua validator ahli, dalam hal ini ialah dosen PGSD Universitas Negeri Malang yakni Drs. Imam Nawawi, M.Si dan Drs. Achmad 
Taufik, M.Pd. Adapun validasi pertama memperoleh hasil bahwa dari keseluruhan item, $90 \%$ dinyatakan sudah cukup sesuai dengan kriteria telaah tanpa harus revisi, dan 10\% kurang sesuai dengan kriteria telaah dan perlu dilakukan revisi. Berdasarkan hasil validasi tersebut, didapatkan kesimpulan bahwa angket layak untuk digunakan setelah diperbaiki. Validasi kedua memperoleh hasil dari keseluruhan item 100\% telah memenuhi kriteria, sehingga dapat disimpulkan bahwa angket dapat digunakan dan bisa lanjut pada langkah berikutnya.

\subsubsection{Uji Reliabilitas}

Pengujian reliabilitas dalam penelitian ini dilakukan dengan bantuan SPSS Statistic 22 dengan ketentuan bahwa apabila hasil perhitungan menggunakan Cronbach Alpha > 0,60, maka angket dinyatakan reliabel. Hasil pengujian reliabilitas angket kecerdasan emosional dapat dilihat pada Tabel 2 .

Tabel 2. Hasil Pengujian Reliabilitas

\begin{tabular}{cc}
\hline \multicolumn{2}{c}{ Reliability Statistics } \\
Cronbach's Alpha & N of Items \\
\hline .712 & 30 \\
\hline
\end{tabular}

Hasil pengujian reliabilitas angket kecerdasan emosional dalam Tabel 2 di atas, yakni diketahui sebesar 0,712. Berdasarkan hasil tersebut, dapat diketahui bahwa angket pada penelitian ini dikatakan reliabel, karena besarnya Cronbach Alpha $>0,60$ atau 0,712 >0,60.

\subsection{Hasil Analisis Data Penelitian}

\subsubsection{Uji Normalitas}

Uji normalitas dilakukan dengan bantuan program SPSS Statistic 22 dan digunakan uji Kolmogorov Smirnov. Hasilnya, dapat dilihat di Tabel 3.

Tabel 3. Hasil Pengujian Normalitas

\begin{tabular}{llcc}
\hline \multicolumn{3}{c}{ One-Sample Kolmogorov-Smirnov Test } \\
\hline $\mathrm{N}$ & & Kecerdasan Emosional Prestasi Belajar \\
Normal Parameters ${ }^{\mathrm{a}, \mathrm{b}}$ & Mean & 131 & 131 \\
& Std. Deviation & 91.08 & 85.1817 \\
\multirow{2}{*}{ Most Extreme Differences } & 9.674 & 8.86108 \\
& Absolute & .062 & .059 \\
& Positive & .050 & .059 \\
Test Statistic & Negative & -.062 & -.048 \\
Asymp. Sig. (2-tailed) & & .062 & .059 \\
\hline
\end{tabular}

a. Test distribution is Normal.

b. Calculated from data.

Berdasarkan hasil uji normalitas tersebut, diperoleh nilai signifikansi kecerdasan emosinal dan prestasi belajar sebesar 0,200 . Suatu data diangap normal jika nilai signifikansi $>$ 0,05 . Variabel kecerdasan emosional dan prestasi belajar menunjukkan 0,200 $>0,005$, sehingga didapatkan kesimpulan bahwa data kedua variabel tersebut berdistribusi normal. 


\subsubsection{Uji Linearitas}

Pengujian linearitas pada penelitian ini dilakukan dengan bantuan SPSS Statistic 22 dengan diperoleh nilai signifikansi sebesar 0,650. Suatu data dapat dikatakan memiliki hubungan yang linear dan signifikan apabila antar variabelnya memiliki nilai signifikansi > 0,05 . Berdasarkan pernyataan tersebut, dapat diambil kesimpulan bahwa variabel kecerdasan emosional dan variabel prestasi belajar berhubungan secara linear dan signifikan, dikarenakan $0,650>0,05$.

\subsubsection{Analisis Regresi Linear Sederhana}

Penggunaan analisis regresi sederhana dimaksudkan untuk pengaruh dari dua variabel yakni variabel bebas (variabel kecerdasan emosional) dan variabel terikat (variabel prestasi belajar). Pengujian analisis regresi linear sederhana dilakukan dengan berbantu program SPSS Statistic 22, dan didapatkan hasil seperti yang tersaji pada Tabel 4.

Tabel 4. Koefisien Regresi

\begin{tabular}{llcccccc}
\hline & & \multicolumn{2}{c}{ Coefficients $^{\mathbf{a}}$} & & & \\
\hline & & \multicolumn{2}{c}{$\begin{array}{c}\text { Unstandardized } \\
\text { Coefficients }\end{array}$} & \multicolumn{2}{c}{$\begin{array}{c}\text { Standardized } \\
\text { Coefficients }\end{array}$} & & \\
\cline { 3 - 5 } & \multicolumn{1}{c}{ Model } & B & Std. Error & Beta & t & Sig. \\
\hline \multirow{2}{*}{1} & (Constant) & 51.912 & 6.916 & & & 7.506 & .000 \\
& Kecerdasan Emosional & .364 & .076 & .390 & & 4.815 & .000 \\
\hline
\end{tabular}

a. Dependent Variable: Prestasi Belajar

Berdasarkan Tabel 4, diketahui bahwa nilai Constant (a) sebesar 51,912, sedangkan nilai kecerdasan emosional (b/koefisien regresi) yakni sebesar 0,364, sehingga dihasilkan persamaan regresi $\mathrm{Y}=\mathrm{a}+\mathrm{bX}$ atau $\mathrm{Y}=51,912+0,364 \mathrm{X}$. Konstanta sebesar 51,912 tersebut memiliki arti bahwa nilai konstan dari variabel prestasi belajar adalah sebesar 51,912. Variabel $\mathrm{X}$ memiliki koefisien regresi 0,364 yang berarti setiap ada pertambahan nilai kecerdasan emosional 1\%, maka akan bertambah pula nilai prestasi belajar sebesar 0,364. Koefisien regresi $\mathrm{X}$ menunjukkan nilai positif, sehingga dapat dikatakan bahwa arah pengaruh variabel $\mathrm{X}$ terhadap variabel $\mathrm{Y}$ adalah positif.

Adapun $t_{\text {hitug }}$ koefisien kecerdasan emosional pada Tabel 4 yakni sebesar 4,815 , untuk dapat mengetahui pengaruh variabel kecerdasan emosional terhadap variabel prestasi belajar adalah melalui cara membandingkan $t_{\text {htung }}$ dengan $t_{\text {abel }}$. Adapun $\mathrm{df}=129$, sebagaimana diperoleh dari rumus $\mathrm{df}=\mathrm{n}-2$, dimana $\mathrm{n}$ adalah jumlah data, yang artinya 131-2 $=129$. Tingkat signifikansi yang digunakan ialah 0,05 , sehingga diperoleh $t_{\text {tbel }}$ sebesar 1,657.

Tingkat signifikansi dari variabel kecerdasan emosional adalah 0,000, dengan begitu dapat ditulis $0,000<0,005$, yang artinya signifikan. Sedangkan $t_{\text {hitumg }}>t_{\text {tabel }}$, yakni $4,815>1,657$, yang berarti terdapat pengaruh positif dan signifikan kecerdasan emosional terhadap prestasi belajar siswa kelas IV SD se-gugus 4 kecamatan Blimbing selama pembelajaran daring. 


\subsection{Pengujian Hipotesis}

Pengujian hipotesis dimaksudkan untuk mengetahui ada tidaknya pengaruh kecerdasan emosional terhadap prestasi belajar siswa kelas IV SD se-gugus 4 kecamatan Blimbing selama pembelajaran daring dengan menggunakan hasil dari uji parsial (T-test). Tingkat signifikansi yang digunakan $5 \%(0,05)$. Apabila nilai signifikansi $\mathrm{t}<0,05$ berarti $\mathrm{H}_{0}$ ditolak, sedangkan jika nilai signifikansi $\mathrm{t}>0,05$ berarti $\mathrm{H}_{0}$ diterima. Adapun pada penelitian ini, hipotesis penelitian dirumuskan seperti berikut.

$\mathrm{H}_{\mathrm{a}}$ : Ada pengaruh positif dan signifikan kecerdasan emosional terhadap prestasi belajar siswa kelas IV SD se-gugus 4 kecamatan Blimbing selama pembelajaran daring.

$\mathrm{H}_{0}$ : Tidak ada pengaruh positif dan signifikan kecerdasan emosional terhadap prestasi belajar siswa kelas IV SD se-gugus 4 kecamatan Blimbing selama pembelajaran daring.

Hasil perhitungan dengan bantuan SPSS Statistic 22 diperoleh nilai 0,000 $<0,005$, maka dalam penelitian ini $\mathrm{H}_{0}$ ditolak dan $\mathrm{H}_{a}$ diterima. Berdasarkan pernyataan tersebut, $\mathrm{H}_{\mathrm{a}}$ yang berbunyi "ada pengaruh positif dan signifikan kecerdasan emosional terhadap prestasi belajar siswa kelas IV SD se-gugus 4 kecamatan Blimbing selama pembelajaran daring” diterima.

\subsection{Pengaruh Kecerdasan Emosional terhadap Prestasi Belajar Siswa Kelas IV SD se-Gugus 4 Kecamatan Blimbing selama Pembelajaran Daring}

Banyak faktor yang dapat mempengaruhi prestasi belajar, salah satunya ialah kecerdasan. Sebagaimana diungkapkan oleh Wahab (2016) bahwa terdapat faktor internal yang dapat mempengaruhi prestasi belajar, dimana salah satunya yakni kecerdasan/intelegensi. Seorang individu sudahlah tentu memiliki kecerdasan atau intelegensi. Sebagaimana diungkapkan oleh Faliyandra (2019) bahwa kecerdasan adalah kemampuan yang ada dalam diri manusia, baik berupa kemampuan kognitif maupun afektif. Kecerdasan pada diri manusia tidak hanya kecerdasan intelektual saja, namun juga terdapat kecerdasan lainnya, salah satunya yaitu kecerdasan emosional.

Prestasi belajar yang baik saat pembelajaran daring tidak sepenuhnya dipengaruhi oleh kecerdasan intelektual dalam diri siswa saja, melainkan ada faktor lain, satu diantaranya ialah kecerdasan emosional. Prestasi belajar yang baik sepenuhnya tergantung pada pengelolaan diri siswa ketika belajar di rumah. Hal tersebut dikarenakan saat pembelajaran daring, guru tidak dapat memantau dan mengawasi kesungguhan belajar siswa secara langsung (Sadikin \& Hamidah, 2020).

Meskipun tantangan pembelajaran daring terkadang membuat semangat belajar siswa menurun, namun seorang siswa dengan kecerdasan emosional yang baik memiliki kemampuan mengatasi tantangan tersebut, karena kecerdasan emosional berkenaan dengan kemampuan siswa dalam mengelola dirinya agar dapat belajar secara mandiri di rumah, mampu memotivasi dirinya agar selalu semangat. Sejalan dengan pernyataan Mashar (2015) yang memandang kecerdasan emosi sebagai kemampuan seseorang dalam mengenali, mengelola, dan mengontrol diri juga orang lain supaya mampu bersikap positif di segala kondisi yang memicu timbulnya emosi. Selain itu, Wahab (2016) menuturkan bahwa kecerdasan emosional merupakan kecakapan seseorang dalam hal mengenali perasaannya 
ketika suatu emosi yang muncul, sehingga dapat mengambil keputusan yang tepat untuk dapat menyikapinya.

Berdasarkan pernyataan di atas, sebagai contoh siswa yang memiliki kecerdasan emosional yang baik, saat rasa malas belajar dalam dirinya muncul, ia akan mampu mengatasi rasa malas tersebut dengan mengelola dirinya kembali dan mampu menyadarkan dirinya bahwa belajar adalah hal yang sudah seharusnya dilakukan sebagai seorang siswa, sedangkan siswa dengan kecerdasan emosional kurang baik, ia akan kesulitan mengelola dirinya saat mengalami rasa malas untuk belajar. Didukung oleh Leoh, dkk (2019) bahwa apabila di dalam diri siswa tidak terdapat kecerdasan emosional yang baik, akan sangat gampang siswa tersebut merasa putus asa dan menyerah saat melakukan aktivitas belajarnya. Hal tersebut berkaitan erat dengan kemampuan memotivasi diri, ketika siswa telah sadar bahwa belajar adalah hal yang harus ia lakukan, selanjutnya ia akan mampu memotivasi dirinya untuk belajar dengan semangat. Seorang siswa yang mampu memotivasi dirinya untuk belajar, berarti ia secara tidak langsung telah mendorong dirinya agar berprestasi dalam belajarnya. Sebagaimana pernyataan Goleman (2003) bahwa aspek memotivasi diri dalam kecerdasan emosional berkenaan dengan kemampuan seseorang dalam memberikan dorongan prestasi kepada dirinya, menetapkan komitmen terhadap tujuan tertentu, dan selalu berpikir positif terhadap hal yang dilakukan. Berdasarkan pernyataan tersebut, Goleman (2003) juga menyebutkan bahwa seseorang yang memiliki kemampuan memotivasi diri, dalam hidupnya akan terus muncul dorongan untuk mencari informasi sebanyak-banyaknya guna meminimalisir ketidakpastian terhadap suatu hal. Apabila dihubungkan dengan siswa, maka apabila siswa memiliki kemampuan memotivasi diri dengan baik, ketika dalam perjalanan belajarnya ia mengalami kesulitan ataupun ketidakpahaman akan materi yang dipelajari, ia tidak akan diam menunggu informasi datang, melainkan ia akan berusaha mencari informasi tersebut, baik melalui pencarian di internet, tanpa malu ia akan bertanya kepada guru, ataupun mencari informasi pada buku lainnya yang dapat menjawab ketidakpahamannya tersebut, sebaliknya jika kecerdasan emosional siswa kurang baik, ia akan kesulitan dalam melakukan tindakan seperti demikian. Didukung oleh Leoh, dkk (2019) yang menyebutkan bahwa seorang siswa yang tidak memiliki kecerdasan emosional yang baik, saat ia menjumpai kendala dalam belajarnya, ia akan malu jika harus bertanya kepada teman maupun gurunya.

Berdasarkan perhitungan analisis regresi linier sederhana pada penelitian ini, didapatkan persamaan $Y=51,912+0,364 X$. Misalnya, sebagai contoh dari siswa kelas IV SD se-gugus 4 kecamatan Blimbing yang memiliki hasil kecerdasan emosional paling rendah, yakni 69, maka perkiraan prestasi belajar yang ia peroleh sebesar 51,912 +0,364(69) =77,028. Selanjutnya, sebagai contoh dari siswa yang memiliki hasil kecerdasan emosional tertinggi, yaitu 116, maka perkiraan prestasi belajar yang didapatkan sebesar 51,912+0,364(116) = 94,136 . Koefisien $X$ bernilai positif, sehingga arah pengaruh variabel $X$ terhadap variabel $Y$ dinyatakan positif. Pada nilai t diketahui hasil thitung $>$ ttabel, yakni 4,815 > 1,657, sehingga koefisien regresi dinyatakan signifikan. Adapun nilai signifikansi atau probabilitas diperoleh $0,000<0,005$, yang berarti variabel $\mathrm{X}$ berpengaruh terhadap variabel $\mathrm{Y}$.

Hasil penelitian ini didukung penelitian terdahulu oleh Rosida (2016) yang menghasilkan kesimpulan bahwa kecerdasan emosional berpengaruh positif dan signifikan terhadap hasil belajar matematika siswa kelas VII 2 SMP Negeri 1 Makassar. Penelitian lainnya yang mendukung penelitian ini yakni penelitian oleh Basir (2019) yang hasilnya menyatakan 
terdapat pengaruh yang signifikan antara kecerdasan emosional dengan prestasi belajar siswa kelas VIII SMPIT Iqra' kota Bengkulu.

Berdasarkan perhitungan yang telah dipaparkan sebelumnya dari hasil penelitian ini, serta didukung oleh penelitian-penelitian terdahulu, diketahui bahwa terdapat pengaruh yang positif dan signifikan kecerdasan emosional terhadap prestasi belajar siswa kelas IV SD segugus 4 kecamatan Blimbing selama pembelajaran daring. Berdasarkan hasil perhitungan itu pula, dapat diinterpretasikan bahwa kecerdasan emosional mempengaruhi prestasi belajar siswa, sehingga semakin tinggi kecerdasan emosional yang dimiliki siswa, maka akan semakin tinggi pula prestasi belajarnya, begitupun sebaliknya.

\section{Simpulan}

Berdasarkan hasil penelitian, diperoleh persamaan $Y=51,912+0,364 \mathrm{X}$ dari analisis regresi linear sederhana, yang artinya nilai konsisten dari variabel Y sebesar 51,912, sedangkan koefisien regresi variabel X sebesar 1,339. Hal tersebut mengandung arti bahwa setiap penambahan $1 \%$ nilai kecerdasan emosional, maka akan bertambah pula nilai prestasi belajar siswa sebesar 0,364 . Koefisien regresi $X$ bernilai positif, sehingga dapat dikatakan bahwa pengaruh dari variabel $\mathrm{X}$ terhadap variabel $\mathrm{Y}$ memiliki arah pengaruh yang positif. Berdasarkan nilai probabilitas yang didapatkan yakni $0,000<0,05$, menunjukkan bahwa variabel X berpengaruh terhadap variabel Y. Pada nilai $t$, diketahui $t_{\text {hitung }} 4,815>t_{\text {tabel }} 1,657$, yang berarti koefisien regresi dinyatakan signifikan. Berdasarkan paparan hasil penelitian tersebut, maka $\mathrm{H}_{\mathrm{a}}$ diterima dan $\mathrm{H}_{0}$ ditolak, sehingga dapat ditarik kesimpulan bahwa terdapat pengaruh positif dan signifikan kecerdasan emosional terhadap prestasi belajar siswa kelas IV SD se-gugus 4 kecamatan Blimbing selama pembelajaran daring.

\section{Daftar Rujukan}

Basir, A. (2019). Pengaruh kecerdasan emosional terhadap prestasi belajar siswa pada mata pelajaran PAI di SMPIT Iqra'kota Bengkulu (Doctoral dissertation, IAIN Bengkulu).

Daud, F. (2012). Pengaruh kecerdasan emosional (EQ) dan motivasi belajar terhadap hasil belajar Biologi siswa SMA 3 Negeri Kota Palopo. Jurnal Pendidikan dan Pembelajaran (JPP), 19(2), 243-255.

Faliyandra, F. (2019). Tri Pusat Kecerdasan Sosial: Membangun Hubungan Baik Antar Manusa pada Lingkungan Pendidikan di Era Teknologi. Malang: CV. Literasi Nusantara Abadi.

Goleman, D. (2003). Kecerdasan Emosi untuk Mencapai Prestasi. Terjemahan Alex Tri Kantjono Widodo. Jakarta: PT Gramedia Pustaka Utama. 1999.

Leoh, R., Djong, K. D., \& Lakapu, M. (2019). Pengaruh Kecerdasan Emosional Terhadap Prestasi Belajar Matematika Pada Siswa Smp Kelas VIII. Asimtot: Jurnal Kependidikan Matematika, 1(1), 13-17.

Mahanani, P., Muchtar, M., Umayaroh, S., Rosyadi, M. I., Sugiarti, I., Resnanda, M., ... \& Saputro, C. (2020). Hubungan Wawasan Kebangsaan Terhadap Prestasi Mahasiswa PGSD dengan Motivasi Sebagai Variabel Moderatingnya (Studi Pada Prodi PGSD di Jawa Timur). Sekolah Dasar: Kajian Teori dan Praktik Pendidikan, 29(1), 28-37. https://doi.org/10.17977/um009v29i12020p028

Marzuki, A., Armereo, C., \& Rahayu, P. F. (2020). Praktikum Statistik. Malang: Ahlimedia Press.

Mashar, R. (2015). Emosi Anak Usia Dini dan Strategi Pengembangannya. Jakarta: Kencana.

Rosida, V. (2016). Pengaruh kecerdasan emosional terhadap hasil belajar matematika siswa kelas VII2 SMP Negeri 1 Makassar. Sainsmat: Jurnal Ilmiah Ilmu Pengetahuan Alam, 4(2).

Sadikin, A., \& Hamidah, A. (2020). Pembelajaran Daring di Tengah Wabah Covid-19:(Online Learning in the Middle of the Covid-19 Pandemic). Biodik, 6(2), 214-224.

Kebudayaan, M. P. D., \& Indonesia, R. (2020). Surat Edaran Nomor 4 Tahun 2020 tentang Pelaksanaan Kebijakan Pendidikan dalam Masa Darurat Penyebaran Coronavirus Disease (COVID-19). 
Jurnal Pembelajaran, Bimbingan, dan Pengelolaan Pendidikan, 1(7), 2021, 552-562

Timotius, K.H. (2017). Pengantar Metodologi Penelitian: Pendekatan Manajemen Pengetahuan untuk Perkembangan Pengetahuan. Yogyakarta: Penerbit Andi.

Wahab, R. (2016). Psikologi Belajar. Depok: PT Rajagrafindo Persada. 